\title{
Potential of Pre-Harvest Wastes of Tobacco (Nicotiana tabacum L.) Crops, Grown for Smoke Products, as Source of Bioactive Compounds (Phenols and Flavonoids)
}

\author{
Maria Isabella Sifola ${ }^{1, * \mathbb{C}}$, Linda Carrino ${ }^{1}\left(\mathbb{D}\right.$, Eugenio Cozzolino $^{2} \oplus$, Luisa del Piano ${ }^{2}$, Giulia Graziani ${ }^{3}(\mathbb{D}$ and \\ Alberto Ritieni ${ }^{3,4}$ (D) \\ 1 Department of Agricultural Sciences, University of Napoli Federico II, Via Università 100, 80055 Portici, Italy; \\ linda.carrino@unina.it \\ 2 CREA-CI, Council for Agricultural Research and Economics-Research Institute for Cereals and Industrial \\ Crops, Via del Torrino 2, 81100 Caserta, Italy; eugenio.cozzolino@crea.gov.it (E.C.); \\ luisa.delpiano@crea.gov.it (L.d.P.) \\ 3 Department of Pharmacy, University of Napoli Federico II, Via Domenico Montesano 49, 80131 Napoli, Italy; \\ giulia.graziani@unina.it (G.G.); alberto.ritieni@unina.it (A.R.) \\ 4 Unesco Chair for Health Education and Sustainable Development, 80131 Napoli, Italy \\ * Correspondence: sifola@unina.it
}

check for updates

Citation: Sifola, M.I.; Carrino, L.; Cozzolino, E.; del Piano, L.; Graziani, G.; Ritieni, A. Potential of Pre-Harvest Wastes of Tobacco (Nicotiana tabacum L.) Crops, Grown for Smoke Products, as Source of Bioactive Compounds (Phenols and Flavonoids). Sustainability 2021, 13, 2087. https:// doi.org/10.3390/su13042087

Received: 22 January 2021

Accepted: 8 February 2021

Published: 16 February 2021

Publisher's Note: MDPI stays neutral with regard to jurisdictional claims in published maps and institutional affiliations.

Copyright: (c) 2021 by the authors. Licensee MDPI, Basel, Switzerland. This article is an open access article distributed under the terms and conditions of the Creative Commons Attribution (CC BY) license (https:// creativecommons.org/licenses/by/ $4.0 /)$.
Abstract: Tobacco cultivation is characterized by high amounts of waste biomasses whose disposal frequently represents a complex and expensive problem. A study was conducted to evaluate thepotential of pre-harvest light air-cured (Burley) and dark fire-cured (Kentucky) tobacco waste biomasses as a source of bioactive compounds (nutraceutical ingredients) such as polyphenols. Preharvest waste materials (topping fresh materials and residual stalks at final harvest) were collected to determine dry matter, total polyphenols content (TPC; Folin assay), and DPPH (2,2-diphenyl-1picrylhydrazyl) and ABTS (2,20-azino-bis(3-ethylbenzothiazoline-60-sulfonic acid) diammonium salt) antioxidant capacity. Polyphenols quali-quantitative profiles obtained by Orbitrap Q Exactive of both tobacco types were also determined. Total pre-harvest waste biomass amounted to 3956.9 and $1304.4 \mathrm{~kg}$ d.w. ha ${ }^{-1}$ in light air-cured (Burley) and dark fire-cured (Kentucky) tobacco types, respectively. Polyphenols content, expressed as $\mathrm{g} \mathrm{kg}^{-1}$ dry weight (d.w.), ranged between 4.6 and $15.7 \mathrm{~g} \mathrm{~kg}^{-1}$ d.w. and was generally greater in leaves than in stalks. Considering both leaves and stalks, the light air-cured (Burley) tobacco crop yielded $22.1 \mathrm{~kg} \mathrm{ha}^{-1}$ of polyphenols, while the dark fire-cured (Kentucky) tobacco yielded $12.0 \mathrm{~kg} \mathrm{ha}^{-1}$. DPPH and ABTS were significantly greater in leaves than in stalks waste biomass in both types of tobacco. The most abundant components were quinic and chlorogenic acids, rutin, and luteolin rutinoside.

Keywords: antioxidant capacity; chlorogenic acid; dark fire-cured tobacco; leaves; light air-cured tobacco; polyphenols; rutin; stalks

\section{Introduction}

Tobacco is a cash crop widely cultivated over the world (3.4 million ha) [1] with 2.0 million ha in Asia, 0.6 million ha in America, 0.6 million ha in Africa, and 0.1 million ha in Europe [1]. Despite of the contraction of the cultivated areas in last 30 years (there were 4.2 million ha just in 2001) [1], it has great economic and social importance in several countries [2], and it is yet considered the most important non-food crop in the world.

At present, 15-7 thousand ha of different types of tobacco are cultivated in Italy $[1,3]$ with the following regional distribution: (i) flue-cured type in Veneto and Umbria (4105 and 5178 ha, respectively; [3,4]), (ii) flue-cured and dark fire-cured types in Tuscany and Lazio (1646 and 411 ha, respectively) [3], and (iii) light air-cured, dark air-cured, and dark fire-cured types in Campania (1911 ha at Caserta province and 1399 ha at Benevento 
province) [3,4]. Currently, Italian tobacco represents $25 \%$ of total European production and $1 \%$ of world production $[1,4]$.

In Campania region (Southern Italy), tobacco is a crop of the tradition (i.e., cultivation of light air-cured Burley type is reportedly started already in 1891), and it has contributed over time to the income, employment, and cultural heritage of entire generations. It has also deeply characterized agricultural landscapes. Despite the alternate but always unfavorable trends of the last two to three decades, tobacco growers continued to cultivate this crop thanks to general good prospects of specific smoke products (i.e., American cigarettes for light air-cured product and Toscano ${ }^{\circledR}$ cigar for dark fire-cured product). Nevertheless, they urgently need to find technical solutions to maintain high-quality standards while adequately covering the high production costs (it is a labor-intensive crop), and it should be possible through additional incomes.

Tobacco cultivation is characterized by high amounts of waste biomasses [5-8]. $\mathrm{Zi}$ et al. [9] reported that more than 68 million tons of tobacco stalks were disposed of worldwide in 2010. Tobacco waste biomasses are currently not fully exploited but, by contrast, their disposal frequently represents a complex problem for growers in a social/economic/environmental key [8].

Tobacco cultivation produces two kind of wastes depending on when they are generated (i.e., in pre- or post-harvest period), which specifically include (i) green materials like discarded leaves, suckers (leaves and stalks), and stalks at the end of the field growing period (pre-harvest waste) or (ii) cured materials like mid ribs, cured leaf, and dust (post-harvest waste).

Differently from energy production, several other environmentally sustainable and profitable plans for using agricultural residual biomasses should be considered as source of additional income $[8,10]$. Some of these plans recommend waste biomass be used as a source of bioactive and healthy compounds, so that a more efficient (sustainable) use of resource factors (fertilizers, water, etc.) could be also achieved. In the case of tobacco, e.g., with the same amount of resource factors ( $\mathrm{N}$ fertilizers, irrigation water, etc.), plant extracts could be also produced together with the cured leaves for smoke products. As a result, both the efficiency of $\mathrm{N}$ and water use could be roughly doubled.

Tobacco biomass contains several useful chemical components [11-14], like alkaloids, proteins and amino acids, phenols, polyphenols, etc. Therefore, tobacco has always been considered a plant with extraordinary properties $[12,15]$. In particular, its alkaloids were studied for their well-known effect against insect $[16,17]$ or in the control of neurological diseases like Alzheimer [18] and Parkinson [19]. Tobacco leaf extracts were also reported to have insecticides effects against mites [20] and larva of the dengue vector mosquitos [21] or antifungal activity against Fusarium spp. [22]. Tobacco stalk extracts showed antibacterial activity [23]. Tobacco biomass also contains high-quality soluble proteins [12,24]. Considering that it generates significant quantities of biomass in a short period of time, it is generally considered an interesting biological reactor [12,24].

Among several chemical components of plant biomass, polyphenols are receiving increasing interest in agriculture, since they protect plants against ultraviolet radiation and some pathogens [25-27] and in addition, they interact with nutritive plants cycling [28]. Polyphenols are also very interesting for food industries, since they show antioxidant capacity, which improve the quality of food products [29-32]. Several studies [33,34] reported that polyphenols have not only simple antioxidant action but could also exert positive modulatory effects in cells through selective activity on pathways involved in the pathogenesis of degenerative diseases. Overall, they improve the wellness state of body.

Polyphenols profile of tobacco is considered relatively simple and well defined [27,35,36]. In particular, tobacco extracts are rich in phenolic acids, mainly chlorogenic acid $[5,27,37]$, and flavonoids represented by rutin [27,37]. Polyphenols profile appears strictly related to different types of tobacco, i.e., Virginia tobacco, Oriental tobacco [38], Nicotiana alata, or Nicotiana rustica [39]. In addition, the polyphenols profile depends on altitude, latitude [40], intensity, quality of light [41,42], age of plant parts [43,44], and water stress [45]. 
No previous study has been conducted to assess polyphenols yield by pre-harvest waste materials (leaves and stalks) of light air-cured (Burley) and dark-fire-cured (Kentucky) tobaccos as well as little information is available on their polyphenol profiles. Considering that (i) there is a potential great amount of pre-harvest waste of both light air-cured (Burley) and dark-fire-cured (Kentucky) tobaccos, (ii) a more efficient and sustainable use of resources is currently highly desirable for these crops, as well as (iii) additional incomes should be needed to cover the high production costs. The basic aim of this research was to determine polyphenols yield and profile and antioxidant properties of both kind of tobacco crops, which are widely cultivated for smoke products in Mediterranean region (Southern Italy).

\section{Materials and Methods}

\subsection{Plant Materials and Samplings}

The experiment was conducted in Campania region (Southern Italy) during 2017 on light air-cured (Burley, cv. PMSP that is local ecotype) and dark fire-cured (Kentucky, cv. KTD8) tobacco crops. Plant materials were collected in a field at the Experimental Station Parco Gussone (Department of Agricultural Sciences, University of Napoli Federico II) located in Portici $\left(40^{\circ} 48.870^{\prime} \mathrm{N} ; 14^{\circ} 20.821^{\prime} \mathrm{E} ; 70 \mathrm{~m}\right.$ a.s.l.). Plants of both kind of tobaccos were grown between May and September. They were regularly fertilized, topped and fully irrigated up to final (commercial) harvest according to standard practices [46,47]. Topping fresh materials (leaves and stalks) of light air-cured (Burley) tobacco and leaves of dark firecured (Kentucky) tobacco, the latter of which emerged after topping despite of treatment for sprouts control and that are currently considered out of commercial product, were sampled and weighted after oven dried at $60^{\circ} \mathrm{C}$ up to constant weight to determine dry matter content. Each topping dry material was then separately prepared to determine total polyphenols and flavonoids content and antioxidant capacity. At the end of the growing period, after the last harvest of commercial leaves, residual stalks were also collected in both tobacco crops, weighted after oven drying at $60{ }^{\circ} \mathrm{C}$ for dry matter content, and prepared for the already reported analytical determinations.

\subsection{Ultrasound-Assisted Extraction of Polyphenolic Compounds}

The extraction of polyphenols was carried out by ultrasound-assisted extraction on lyophilized samples following the procedure reported in Banožić et al. [14] with a few modifications. Before extraction, lyophilized samples were ground in a mill IKA A11 (IKAWerke, Staufen, Germany). In particular, $3 \mathrm{~g}$ of dried sample were extracted with $30 \mathrm{~mL}$ of ethanol/water $(50: 50 \mathrm{v} / \mathrm{v})$, the mixture was vortexed intensively for $1 \mathrm{~min}$ and sonicated in the dark, at room temperature, for $30 \mathrm{~min}$. After centrifugation $(4000 \mathrm{rpm} / \mathrm{min})$ at $4{ }^{\circ} \mathrm{C}$ for $10 \mathrm{~min}$, samples were filtered through $0.22 \mu \mathrm{m}$ nylon filters (Phenomenex, Castel Maggiore, Italy) and then used for high-resolution mass spectrometry analysis, total polyphenolic content, and antioxidant activity assay. The extraction procedure was repeated three times.

\subsection{Total Polyphenolic Content Assay (Folin)}

Folin assay was used to estimate total polyphenolic content (TPC) in the tobacco leaves and stalks extracts. In this assay, the Folin reagent reacts with phenolic compounds forming a blue complex due to electron transfer [48]. In brief, $125 \mu \mathrm{L}$ of extract properly diluted with extractive mixture [14] was mixed with the same volume of Folin-Ciocalteu reagent and $500 \mu \mathrm{L}$ of deionized water; then, it was incubated at room temperature for $6 \mathrm{~min}$. Further, $1250 \mu \mathrm{L}$ of a $7.5 \%$ sodium carbonate solution were added to the mixture, and the volume was adjusted to $3 \mathrm{~mL}$ with water. The absorbance was measured at $760 \mathrm{~nm}$ after $90 \mathrm{~min}$ at room temperature. Results were expressed as gallic acid equivalent (g GAE kg ${ }^{-1}$ d.w.).

\subsection{Determination of Antioxidant Activity (ABTS and DPPH Assay)}

The 2,20-azino-bis(3-ethylbenzothiazoline-60-sulfonic acid) diammonium salt (ABTS) and 2,2-diphenyl-1-picrylhydrazyl (DPPH) were used as standards. 
The antioxidant potential of the extracts with DPPH was measured according to the procedure described by Brand-Williams et al. [49], with minor modifications. In brief, methanolic DPPH solution $(4 \mathrm{mg} / 10 \mathrm{~mL})$ was diluted with methanol to obtain an absorbance of $1.000 \pm 0.020$ at $517 \mathrm{~nm}$ (working solution). Afterward, $1000 \mu \mathrm{L}$ of this solution was added to $200 \mu \mathrm{L}$ of the studied extract, mixed, and incubated at room temperature for $10 \mathrm{~min}$. The absorbance was monitored at $517 \mathrm{~nm}$, and results were expressed as Trolox equivalents (mmol TE kg-1 d.w.).

To evaluate the antioxidant activity of the tobacco extracts, the ABTS method was also applied according the procedure described by Re et al. [50], with minor modifications. In particular, a $7 \mathrm{mM}$ solution of ABTS in $2.45 \mathrm{mM}$ aqueous potassium persulfate was prepared, and after $16 \mathrm{~h}$ of incubation in the dark at room temperature, the solution was diluted with ethanol to obtain an absorbance of $1.000 \pm 0.020$ at $734 \mathrm{~nm}$. Then, $100 \mu \mathrm{L}$ of the extract was added to $1000 \mu \mathrm{L}$ of this solution. Measurements of absorbance were taken at $734 \mathrm{~nm}$ after $2.5 \mathrm{~min}$ of incubation. In addition, Trolox was used as the reference and activities were expressed as Trolox equivalents (mmol TE kg ${ }^{-1}$ d.w.).

\subsection{Orbitrap High-Resolution Mass Spectrometry Analysis}

The Orbitrap analysis was used to determine polyphenols profile of both kind of tobaccos applying conditions as reported in Graziani et al. [51]. Chromatographic analysis was carried out through an UHPLC system (UHPLC, Thermo Fisher Scientific, Waltham, MA, USA), equipped with a Dionex Ultimate 3000 Quaternary pump and a thermostated $\left(25^{\circ} \mathrm{C}\right.$ ) Kinetex $1.7 \mu \mathrm{m}$ biphenyl $(10 \mathrm{~mm} \times 2.1 \mathrm{~mm}$ ) column (Phenomenex, Torrance, CA, USA), with the following analytical conditions: solvent A, water/formic acid (99.9:0.1); solvent B, methanol/formic acid (99.9:0.1); flow rate, $0.2 \mathrm{~mL} / \mathrm{min}$.; and injection volume, $2 \mu \mathrm{L}$. The auto-sampler and column temperatures were set at 10 and $25^{\circ} \mathrm{C}$, respectively. A gradient elution program was applied as follows: $0 \mathrm{~min}, 5 \%$ of phase $\mathrm{B} ; 1.3 \mathrm{~min}, 30 \%$ of phase $\mathrm{B} ; 9.3 \mathrm{~min}, 100 \%$ of phase $\mathrm{B} ; 11.3 \mathrm{~min}, 100 \%$ of phase $\mathrm{B} ; 13.3 \mathrm{~min}, 5 \%$ of phase B; $20 \mathrm{~min}, 5 \%$ of phase $\mathrm{B}$. The mass spectrometry analysis was facilitated by a $\mathrm{Q}$ Exactive Orbitrap LC-MS/MS (Thermo Fisher Scientific, Waltham, MA, USA) that was equipped with an electrospray (ESI) source operating in negative ion mode (Thermo Scientific, Bremen, Germany). The acquisitions were conducted by setting a Full MS/AIF mode that uses a full MS scan (without HCD fragmentation), followed by an all-ion fragmentation (AIF) scan (with a fragmentation energy applied). Full MS experiments were carried out with settings: microscans, 1; AGC target, $1 \times 10^{6}$; maximum injection time, 200 ms; mass resolution, 35,000 FWHM at $m / z$ 200, whereas the AIF scan conditions were: microscans, 1; AGC target, $1 \times 10^{5}$; maximum injection time, $200 \mathrm{~ms}$; mass resolution, 17,500 FWHM at $m / z$ 200; HCD energy, at 10, 20, and 45. In both cases, the instrument was set to spray voltage, $3.5 \mathrm{kV}$; capillary temperature, $275^{\circ} \mathrm{C}$; sheath gas, 45 (arbitrary units); auxiliary gas, 10 (arbitrary units); $m / z$ range, $80-1200$; data acquisition, profile mode. The accuracy of MS analysis was ensured by calibrating the detector using the commercial calibration solutions that were provided by the manufacturer. Mass tolerance was kept at $5 \mathrm{ppm}$ in both full-scan MS and AIF modes. Xcalibur software v. 3.1.66.10 (Xcalibur, Thermo Fisher Scientific, Waltham, MA, USA; v. 3.0.63) was used to perform data analysis and processing. Polyphenols content, as $\mathrm{g} \mathrm{kg}^{-1}$, was obtained by summing contents of different components within each profile.

\subsection{Statistical Analyses}

All results, separately for each tobacco type, were subjected to ANOVA [52] with a onefactor complete randomized block design, and means were separated by least significant differences (LSD) test. 


\section{Results and Discussion}

\subsection{Yield in Waste Biomass and Polyphenols}

Polyphenols have several health or nutraceutical properties that are well accepted by the scientific community. In particular, with regard to food application, a diet rich in polyphenols is recommended to improve the quality of life and reduce the risk of chronic diseases $[29,33]$. Considering the increasing interest for such substances, more and more attention is being given to new natural sources of such compounds.

As previously reported, in this study, we used the ultrasound-assisted extraction, which allows to use less organic solvent but gives greater extraction yields as compared to conventional techniques [14]. In addition, it also permits to shorten the extraction times [14].

Total pre-harvest waste biomass of the present experiment (sprouts materials and residual stalks) amounted to 3956.9 and $1304.4 \mathrm{~kg}$ d.w. ha ${ }^{-1}$ in light air-cured (Burley) and dark fire-cured (Kentucky) tobaccos, respectively (Table 1), in agreement with previously reported for both types of tobacco $[46,47]$. In particular, those previous field studies, conducted in the same cultivation areas, showed that it accounts for about $50 \%$ of the total biomass usually produced by both crops grown for smoke products $[46,47]$. Higher planting density usually applied in the field for light air-cured (Burley) than dark fire-cured (Kentucky) tobacco (30,000 vs. 10,000 plants $\mathrm{ha}^{-1}$, respectively), due to different plant structure and shape (slim and cylindrical, respectively, in light air-cured tobacco; robust and conic, respectively, in dark fire-cured tobacco), was the main reason of greater preharvest biomass, and consequently, greater wastes, produced per land area by Burley than Kentucky crops.

Table 1. Waste biomass, polyphenols content, and yield in light air-cured (Burley) and dark fire-cured (Kentucky) tobaccos.

\begin{tabular}{|c|c|c|c|c|c|c|c|}
\hline & & \multicolumn{2}{|c|}{$\begin{array}{l}\text { Waste Biomass } \\
\left(\text { kg d.w. ha }^{-1}\right)\end{array}$} & \multicolumn{2}{|c|}{$\begin{array}{l}\text { Polyphenols Content }{ }^{1} \\
\quad\left(\mathrm{~g} \mathrm{~kg}^{-1} \text { d.w. }\right)\end{array}$} & \multicolumn{2}{|c|}{$\begin{array}{l}\text { Polyphenols Yield } \\
\qquad\left(\mathrm{kg} \mathrm{ha}^{-1}\right)\end{array}$} \\
\hline & & Burley & Kentucky & Burley & Kentucky & Burley & Kentucky \\
\hline \multirow{2}{*}{$\begin{array}{l}\text { Topping } \\
\text { materials }\end{array}$} & Leaf & $482.7 \mathrm{~B}$ & 191.6 & $12.6 \mathrm{a}$ & 15.7 & $6.1 \mathrm{~B}$ & 3.0 \\
\hline & Stalk & $254.5 \mathrm{~B}$ & - & $5.2 \mathrm{~b}$ & - & $1.3 \mathrm{~B}$ & - \\
\hline $\begin{array}{l}\text { Residual } \\
\text { biomass }^{2}\end{array}$ & Stalk & $3219.7 \mathrm{~A}$ & 1112.8 & $4.6 \mathrm{~b}$ & 8.1 & $14.7 \mathrm{~A}$ & 9.0 \\
\hline Significance & & $* *$ & NS & * & NS & $* *$ & NS \\
\hline
\end{tabular}

${ }^{1}$ Orbitrap; ${ }^{2}$ at final harvest. Different letters within columns indicate least significant differences at $p \leq 0.05$ and $p \leq 0.01$ (capital letters) between different plant materials. NS, not significant; ${ }^{*}$, significant at $p \leq 0.05 ;{ }^{* *}$, significant at $p \leq 0.01$; d.w., dry weight.

Different plant parts were compared and most of the pre-harvest waste biomass in both tobacco types came, as expected, from residual stalks (Table 1).

$\mathrm{Zi}$ et al. [9] reported a pre-harvest stalks waste of about $25 \%$ of commercial leaves output. Zhang et al. [53] measured, during cigarette processing, a residual leaves waste of more than $20 \%$. Selvamuthukumaran and Shi [54] also measured similar percentage amounts of waste materials for other species, which, nevertheless, were by-products of industrial processing (i.e., post-harvest waste biomasses). In particular, in their review, they cited experiments that reported percentages of by-products both equal or slightly lower ( $40 \%$ in agave or $15-40 \%$ in potato) and slightly greater $(60 \%$ in artichoke or about $65 \%$ in orange) than those we found in tobacco.

Regardless of tobacco types, the polyphenols content, expressed as $\mathrm{g} \mathrm{kg}^{-1}$ d.w., ranged between 4.6 and $15.7 \mathrm{~g} \mathrm{~kg}^{-1}$ and was generally greater in leaves than in stalks but significantly only in light air-cured (Burley) tobacco (Table 1). Regardless of different organs, polyphenols content of the present experiment for both types of tobacco was lower than that found by Leffingwell [11], which ranged between $1.78 \%$ and $2.05 \%$ or between $2.78 \%$ and $3.64 \%$, in Burley or dark fire-cured tobaccos, respectively. In the present experiment, 
light air-cured (Burley) tobacco did not show significant difference in polyphenols content between stalks sampled at topping or those collected at final harvest (Table 1).

Comparing with other species, tobacco polyphenols content, averaged on leaves and stalks, was close to the values reported for grapes (5-25 mg g ${ }^{-1}$ d.w.) [55] and pepper

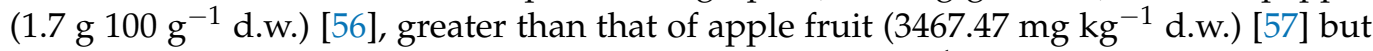
lower than that found in artichoke $\left(7564.7-9861.6 \mathrm{mg} 100 \mathrm{~g}^{-1} \mathrm{~d} . \mathrm{w}\right.$. in primary heads and $3174.8-5309.8 \mathrm{mg} 100 \mathrm{~g}^{-1}$ d.w. in secondary heads) [32] or seeds and flowers of safflower (40-126 mg g ${ }^{-1}$ d.w.) [57].

Interestingly, when we consider the yield of polyphenols as kilogram per hectare, we found greater values in stalks than in leaves (16 vs. $6.1 \mathrm{~kg} \mathrm{ha}^{-1}$ and $9 \mathrm{vs.} 3 \mathrm{~kg} \mathrm{ha}^{-1}$ in light air-cured and dark fire-cured tobaccos, respectively; Table 1). This result was due to the previously reported greater amount of stalk than leaf waste biomass produced by crops. Therefore, it should be convenient to collect stalks after the final harvest to have extracts rather than to bury them, as usually occurs [8], even because their burial could increase the risk of epidemics for many diseases due to survival of some infectious microorganisms on those biomasses [58].

On the whole, by summing yield of polyphenols from leaves and stalks, the light air-cured (Burley) tobacco crop yielded $22.1 \mathrm{~kg} \mathrm{ha}^{-1}$, while the dark fire-cured (Kentucky) tobacco yielded $12.0 \mathrm{~kg} \mathrm{ha}^{-1}$ (Table 1). Market prices of commercial plant extract polyphenols powders ranged, on average, between 10 and 100 USD per kg (rarely more) [59] depending on their purity or percentage concentration of polyphenols. Then, the potential extra gross income could range between 221 and 2210 USD (about 184-1840 $€$ ) for light air-cured (Burley) type and 120 and 1200 USD (about 101-1010 $€$ ) for dark fire-cured (Kentucky) type. Therefore, these extras should be relevant for tobacco growers even though potential costs to prepare waste biomasses for further industrial processing and other potential additional costs have to be also considered.

TPC, expressed as g GAE kg${ }^{-1}$ d.w., is reported in Table 2. The leaf content of both tobacco types was close to that reported by Ru et al. [60] (23.2 $\left.\mathrm{mg} \mathrm{GAE}^{-1}\right)$.

Table 2. Total polyphenols content (TPC, g GAE kg-1 d.w.) in light air-cured (Burley) and dark fire-cured (Kentucky) tobaccos.

\begin{tabular}{lccc}
\hline & \multicolumn{2}{c}{ TPC (g GAE kg ${ }^{-1}$ d.w.) } \\
\hline & & Burley & Kentucky \\
\hline Topping materials & Leaf & $18.1 \mathrm{a}$ & $22.4 \mathrm{~A}$ \\
& Stalk & $5.6 \mathrm{~b}$ & - \\
Residual biomass ${ }^{1}$ & Stalk & $3.8 \mathrm{~b}$ & $8.1 \mathrm{~B}$ \\
\hline \multicolumn{2}{c}{ Significance } & $*$ & $*$ \\
\hline${ }^{1}$ At final harvest. Different letters within columns indicate least significant differences at $p \leq 0.05$ and $p \leq 0.01$ \\
(capital letters) between different plant materials. ${ }^{*}$, significant at $p \leq 0.05 ;{ }^{* *}$, significant at $p \leq 0.01 ;$ d.w., dry \\
weight; GAE, gallic acid equivalent.
\end{tabular}

Regardless of tobacco types, TPC was higher in leaves than in stalks (Table 2) according to that reported by Sheen [61] and Ben Nasr et al. [43]. In particular, Ben Nasr et al. [43] measured amounts of leaf and stalk TPC similar to those of the present experiment (14.46 and $23.05 \mathrm{mg} \mathrm{GAE} \mathrm{g}^{-1}$ in leaves of adult and young plants, respectively; 5.70 and $5.33 \mathrm{mg} \mathrm{GAE} \mathrm{g}^{-1}$ in stalks of adult and young plants, respectively). In addition, in our experiment, light air-cured (Burley) tobacco did not show significant difference in TPC between stalks harvested at topping and those collected at final harvest (Table 2). Finally, when we compared different tobacco types, we found that both plant parts (leaves and stalks) of dark fire-cured (Kentucky) tobacco contained more TPC than light air-cured (Burley) one (Table 2). 


\subsection{Radical Scavenging Activity (DPPH, ABTS, and \% Inhibition)}

As already reported, phenolic compounds are known to possess biological properties including antioxidant activity, which aims to scavenge free radicals or preventing their formation. In the present experiment, the radical scavenging of tobacco extract (leaf and stalk, separately) was determined using two well-known spectrophotometric assays by determining DPPH and ABTS free radical scavenging activity. The results are reported in Table 3.

Table 3. DPPH (2,2-diphenyl-1-picrylhydrazyl) and ABTS (2,20-azino-bis(3-ethylbenzothiazoline60-sulfonic acid) diammonium salt) radical-scavenging activity in light air-cured (Burley) and dark fire-cured (Kentucky) tobaccos.

\begin{tabular}{|c|c|c|c|c|c|}
\hline & & \multicolumn{2}{|c|}{$\begin{array}{c}\text { DPPH } \\
\left(\mathrm{mmol} \mathrm{TE} \mathrm{kg}^{-1} \text { d.w. }\right)\end{array}$} & \multicolumn{2}{|c|}{$\begin{array}{c}\text { ABTS } \\
\left(\mathrm{mmol} \mathrm{TE} \mathrm{kg}^{-1} \text { d.w. }\right)\end{array}$} \\
\hline & & Burley & Kentucky & Burley & Kentucky \\
\hline \multirow[t]{2}{*}{ Topping materials } & Leaf & $46.3 \mathrm{a}$ & $56.4 \mathrm{a}$ & 61.0 & $70.7 \mathrm{~A}$ \\
\hline & Stalk & $7.7 \mathrm{~b}$ & - & 10.0 & - \\
\hline Residual biomass ${ }^{1}$ & Stalk & $11.2 \mathrm{~b}$ & $13.1 \mathrm{~b}$ & 7.8 & $7.5 \mathrm{~B}$ \\
\hline Significance & & * & * & NS & ** \\
\hline
\end{tabular}

${ }^{1}$ At final harvest. Different letters within columns indicate least significant differences at $p \leq 0.05$ and $p \leq 0.01$ (capital letters) between different plant materials. d.w., dry weight. ${ }^{*}$, significant at $p \leq 0.05$; ${ }^{* *}$, significant at $p \leq 0.01$. TE, Trolox equivalent.

Overall, the antioxidant capacity was higher in the leaves than in the stalks in both types of tobacco (Table 3) and the dark fire-cured (Kentucky) extracts showed a higher antioxidant activity compared to light air-cured (Burley) ones (Table 3). Ru et al. [60] reported that flavonoids of tobacco leaves were good antioxidants with strong DPPH radical scavenging activity.

Rodu and Ou [62] showed that the antioxidant activity of commercially tobacco products, measured as ORAC, varied from 66 to $230 \mu \mathrm{mol} \mathrm{TE} \mathrm{g}^{-1}$ on a dry weight basis. Our results are in line with these results regarding the leaves while lower antioxidant activity values were obtained for stalks by both DPPH and ABTS methods. Interestingly, the range of activity in the tobacco leaves was similar to that reported for many fruits and vegetables [63].

Results of antioxidant activity were consistent with those of Folin assay, since there was a good linear and highly significant correlation between the TPC and the antioxidant capacity (Figure $1 ; r=0.901$ and $r=0.913$, for DPPH and ABTS respectively; $n=28$ ) without appreciable differences between DPPH and ABTS. This result showed that polyphenols greatly contributed to the antioxidant activity of tobacco extracts. Strong correlations between both DPPH and ABTS and TPC were also found in artichoke [32], Thymus species [64], and mango fruits [65].

The percentage of inhibition of free radicals of leaves and stalks was similar in both kind of tobaccos, with average values of 45.1 ( \pm 3.4 standard error) and 19.7 ( \pm 2.9 standard error) in leaf and stalk, respectively, for DPPH, and of 32.9 ( \pm 2.1 standard error) and 17.3 ( \pm 0.5 standard error) in leaf and stalk, respectively, for ABTS. These values were lower than those reported by Sharma et al. [7] who found in tobacco a percentage of inhibition of free radicals ranging between 43.8 and 70.9 . 

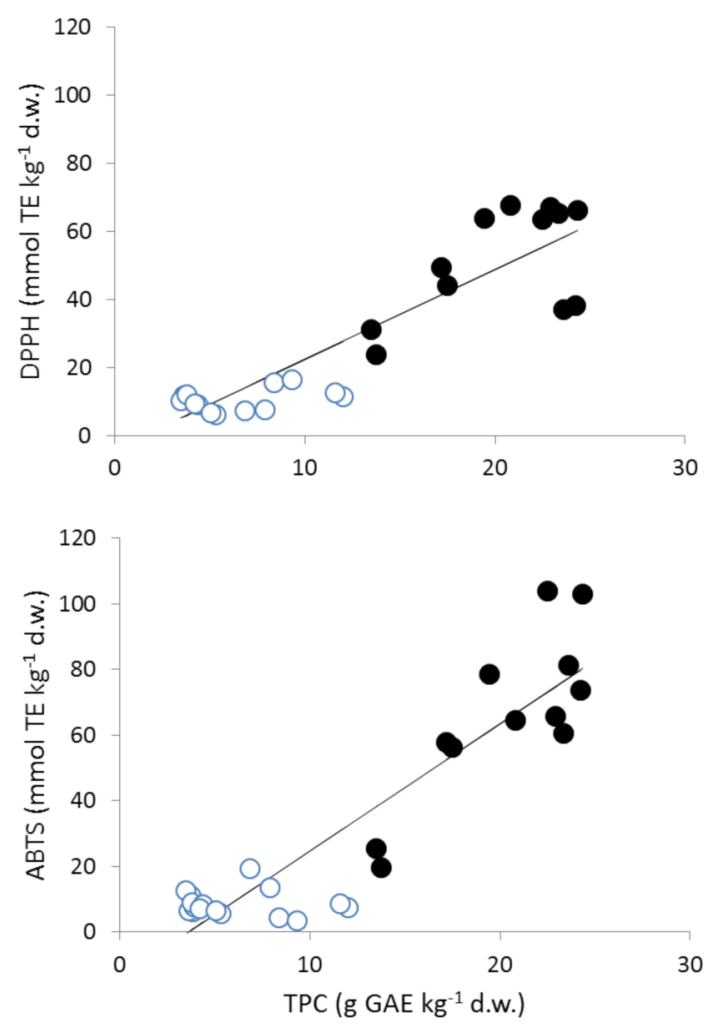

Figure 1. DPPH (2,2-diphenyl-1-picrylhydrazyl) and ABTS (2,20-azino-bis(3-ethylbenzothiazoline60-sulfonic acid) diammonium salt) antioxidant activity versus TPC. TPC, total polyphenols content; TE, Trolox equivalent; GAE, gallic acid equivalent; d.w., dry weight. Equations: $\mathrm{Y}=-4.03+2.64 \mathrm{X}, \mathrm{r}=0.901 * *(\mathrm{DPPH}) ; \mathrm{Y}=-14.01+3.87 \mathrm{X}, \mathrm{r}=0.913{ }^{* *}(\mathrm{ABTS}) .{ }^{* *}$, significant at $p \leq 0.01$. o, stalks; $\bullet$, leaves.

\subsection{Phenolic Profile: Phenolic Acids and Flavonoids}

Tobacco phenolic profiles are reported in Tables 4 and 5. In both tobacco types, the most abundant components were quinic and chlorogenic acids (Table 4) and rutin and luteolin rutinoside (Table 5). Leaves were richer in phenolic acids and flavonoids compounds than in stalks and differences were usually significant in both tobacco types (Tables 4 and 5).

Table 4. Phenolic acids ( $\mathrm{mg} \mathrm{kg}^{-1}$ d.w.) in light air-cured (Burley) and dark fire-cured (Kentucky) tobaccos.

\begin{tabular}{|c|c|c|c|c|c|c|c|c|}
\hline Burley & & Quinic Acid & $\begin{array}{l}\text { Chlorogenic } \\
\text { Acid }\end{array}$ & Caffeic Acid & $\begin{array}{c}\text { 5-O-p- } \\
\text { Coumaroyl } \\
\text { Quinic Acid }\end{array}$ & $\begin{array}{l}\text { Feruloyl } \\
\text { Quinic Acid } \\
\text { Isomer 1 }\end{array}$ & $\begin{array}{c}\text { 3-O-p- } \\
\text { coumaroyl } \\
\text { Quinic Acid }\end{array}$ & $\begin{array}{l}\text { Feruloyl } \\
\text { Quinic Acid } \\
\text { Isomer } 2\end{array}$ \\
\hline \multirow[t]{2}{*}{$\begin{array}{l}\text { Topping } \\
\text { materials }\end{array}$} & Leaf & 3926.2 & 2339.9 & 6.87 & $53.5 \mathrm{~A}$ & $45.3 \mathrm{a}$ & $64.0 \mathrm{a}$ & $20.8 \mathrm{a}$ \\
\hline & Stalk & 4398.0 & 491.8 & 1.31 & $5.8 \mathrm{~B}$ & $2.2 \mathrm{~b}$ & $4.6 \mathrm{~b}$ & $1.9 \mathrm{~b}$ \\
\hline $\begin{array}{l}\text { Residual } \\
\text { biomass }^{1}\end{array}$ & Stalk & 3153.0 & 1198.0 & 3.58 & $5.5 \mathrm{~B}$ & $2.1 \mathrm{~b}$ & $5.0 \mathrm{~b}$ & $2.0 \mathrm{~b}$ \\
\hline Significance & & NS & NS & NS & $* *$ & * & * & * \\
\hline Kentucky & & Quinic Acid & $\begin{array}{l}\text { Chlorogenic } \\
\text { Acid }\end{array}$ & Caffeic Acid & $\begin{array}{c}\text { 5-O-p- } \\
\text { Coumaroyl } \\
\text { Quinic Acid }\end{array}$ & $\begin{array}{l}\text { Feruloyl } \\
\text { Quinic Acid } \\
\text { Isomer 1 }\end{array}$ & $\begin{array}{c}\text { 3-O-p- } \\
\text { Coumaroyl } \\
\text { Quinic Acid }\end{array}$ & $\begin{array}{l}\text { Feruloyl } \\
\text { Quinic Acid } \\
\text { Isomer } 2\end{array}$ \\
\hline $\begin{array}{l}\text { Topping } \\
\text { materials }\end{array}$ & Leaf & 1980.0 & $4777.5 \mathrm{a}$ & $14.2 \mathrm{a}$ & $88.7 \mathrm{a}$ & 69.8 & $63.3 \mathrm{a}$ & $23.7 \mathrm{a}$ \\
\hline $\begin{array}{l}\text { Residual } \\
\text { biomass }^{1}\end{array}$ & Stalk & 6925.5 & $1998.6 \mathrm{~b}$ & $1.7 \mathrm{~b}$ & $9.5 \mathrm{~b}$ & 4.7 & $6.5 \mathrm{~b}$ & $3.9 \mathrm{~b}$ \\
\hline Significance & & NS & $*$ & $*$ & * & NS & * & $*$ \\
\hline
\end{tabular}

${ }^{1}$ At final harvest. Different letters within columns indicate least significant differences at $p \leq 0.05$ and $p \leq 0.01$ (capital letters) between different plant materials. NS, not significant; ${ }^{*}$, significant at $p \leq 0.05 ;{ }^{* *}$, significant at $p \leq 0.01$; d.w., dry weight. 
Table 5. Flavonoids (mg kg ${ }^{-1}$ d.w.) in light air-cured (Burley) and dark fire-cured (Kentucky) tobaccos.

\begin{tabular}{|c|c|c|c|c|c|c|}
\hline Burley & & Scopoletin & Isoscopoletin & Rutin & Isoquercetin & $\begin{array}{l}\text { Luteolin } \\
\text { Rutinoside }\end{array}$ \\
\hline \multirow[t]{2}{*}{ Topping materials } & Leaf & 15.2 & 10.7 & 4830.3 & 44.6 & $1250.0 \mathrm{a}$ \\
\hline & Stalk & 108.2 & 48.3 & 150.5 & 1.4 & $14.3 \mathrm{~b}$ \\
\hline Residual biomass ${ }^{1}$ & Stalk & 45.1 & 15.9 & 117.1 & 0.8 & $9.2 \mathrm{~b}$ \\
\hline Significance & & NS & NS & NS & NS & * \\
\hline Kentucky & & Scopoletin & Isoscopoletin & Rutin & Isoquercetin & $\begin{array}{c}\text { Luteolin } \\
\text { Rutinoside }\end{array}$ \\
\hline Topping materials & Leaf & 48.0 & 30.0 & $7401.1 \mathrm{~A}$ & $75.3 \mathrm{~A}$ & $1152.2 \mathrm{~A}$ \\
\hline Residual biomass ${ }^{1}$ & Stalk & 177.7 & 108.3 & $127.8 \mathrm{~B}$ & $1.2 \mathrm{~B}$ & $16.8 \mathrm{~B}$ \\
\hline Significance & & NS & NS & $* *$ & $* *$ & $* *$ \\
\hline
\end{tabular}

In dark fire-cured (Kentucky) tobacco, the chlorogenic, caffeic acids, rutin, isoquercetin, and luteolin rutinoside contents were significantly higher in leaves than in stalks (Tables 4 and 5) as well as luteolin rutinoside content in light air-cured (Burley) tobacco (Tables 4 and 5). Leaves of both tobacco types were also significantly richer than stalks in 5-O-p-coumaroyl quinic acid and 3-O-p-coumaroyl quinic acid contents (Table 4).

Regardless of tobacco type, Wang et al. [27] also reported that the dominant polyphenols in tobacco leaves were chlorogenic acid and rutin. Similar profile was also found in Virginia and Oriental tobaccos [66] and in light air-cured (Burley) tobacco [67]. Chlorogenic acid and rutin contents in both light air-cured (Burley) and dark fire-cured (Kentucky) tobacco of our experiment were comparable to that reported for other kind of tobacco (Oriental) [68] or for some medicinal species [69]. Both compounds are of relevant interest for industry.

Rutin is frequently used as cosmetic ingredients [70-72]. Chlorogenic acid, which is a major component of coffee [73] but also present in several fruits and vegetables (apple, tomato, potato, eggplant, etc.), is reported to reduce blood pressure and weight [74].

\section{Conclusions}

The quality of tobacco waste extracts appeared very interesting because their contents of functional ingredients such as phenolic acids or flavonoids as rutin were sufficiently high to consider the wastes of tobacco as economic and convenient natural sources of these salutistic compounds.

It should be considered that the trend of the market of food integrator, nutraceuticals, or functional ingredients is continuously raising up despite the economic crisis and the COVID-19 pandemic. Food transformer industries use different kinds of extracts to fortify the conventional foods by phenolic compounds and often they use synthetic phenolic antioxidants permitted in foods (i.e., butylated hydroxyanisole, BHA, butylated hydroxytoluene, BHT, propyl gallate, PG, tertiary-butylhydroquinone, TBHQ, etc.). Nevertheless, due to safety concerns and consumer request of natural products, natural antioxidants obtained not only from edible materials and edible by-products but also from residual sources are receiving increasing interest, and thus, the market is going toward naturals polyphenols.

Food industries are always in search of new natural ingredients or, alternatively, the same molecules but much more economic ones; in this view, considering results of the present study, new good opportunities should be opened for tobacco crops.

We consider of great importance the high percentage of pre-harvest wastes produced by both light air-cured and dark fire-cured tobacco crops and the good quality of their extracts. Such wastes should be conveniently, and also preferably, used as source of polyphe- 
nols, and sustainable goals of improving the efficiency of use of crop resources factors (water, $\mathrm{N}$, etc.) would be also achieved. Moreover, after the extraction, the residual nicotinefree organic matter could be recovered for the production of bio-amendments (i.e., from microorganisms and/or pyrolysis), allowing additional favorable environmental effects.

Further investigations will be necessary to correctly quantify the economic advantage of farmers due to the new products, taking into account the costs of pre-treatments (drying, cutting, etc.) and of delivery of waste biomasses for subsequent industrial extraction.

Author Contributions: Conceptualization, M.I.S.; methodology, M.I.S. and A.R.; validation, E.C., L.C., and G.G.; formal analysis, E.C., L.C., and G.G.; investigation, M.I.S. and A.R.; resources, M.I.S. and A.R.; data curation, M.I.S., E.C., L.C., and G.G.; writing-original draft preparation, M.I.S.; writing-review and editing, M.I.S., A.R., and L.d.P.; visualization, M.I.S. and L.d.P.; supervision, M.I.S.; project administration, M.I.S. and A.R.; funding acquisition, M.I.S. and A.R. All authors have read and agreed to the published version of the manuscript.

Funding: This research received no external funding.

Institutional Review Board Statement: Not applicable.

Informed Consent Statement: Not applicable.

Data Availability Statement: The data presented in this study are available on request from the corresponding author.

Conflicts of Interest: The authors declare no conflict of interest.

\section{References}

1. Food and Agriculture Organization. FAOSTAT. Available online: http://www.fao.org/faostat/en/\#data/QL (accessed on 8 January 2021).

2. FAO. The economic significance of tobacco. Econ. Soc. Dev. Pap. 1989, 85, 90.

3. ISTAT. 2018. Available online: http:/ / dati.istat.it/ (accessed on 8 January 2021).

4. Nomisma. La Filiera del Tabacco in Italia. Impatto Socioeconomico ed Aspetti di Politica Fiscale; XV Rapporto; Nomisma: Bologna, Italy, 2012; pp. 83-84.

5. Rawat, A.; Mali, R.R.; Saini, A.K.; Chauhan, P.K.; Singh, V.; Sharma, P. Phytochemical Properties and Pharmcological Activities of Nicotiana Tabacum: A Review. Indian J. Pharm. Biol. Res. 2013, 1, 74-82. [CrossRef]

6. Novotny, T.E.; Slaughter, E. Tobacco Product Waste: An Environmental Approach to Reduce Tobacco Consumption. Curr. Environ. Heal. Rep. 2014, 1, 208-216. [CrossRef]

7. Sharma, Y.; Nagar, A.; Srivastava, N.S.; Bala, K. Antioxidant Activity of Polyphenolic Flavonoid of Stem of Nicotiana tabacum. Am. J. Drug Discov. Dev. 2016, 7, 25-32. [CrossRef]

8. Barla, F.G.; Kumar, S. Tobacco biomass as a source of advanced biofuels. Biofuels 2016, 10, 335-346. [CrossRef]

9. Zi, W.; Zhang, X.; Peng, J.; Zhang, L.; Long, M.; Zuo, J. Optimization of Microwave Drying Biomass Material of Stem Granules from Waste Tobacco Using Response Surface Methodology. Dry. Technol. 2013, 31, 1234-1244. [CrossRef]

10. Andrianov, V.; Borisjuk, N.; Pogrebnyak, N.; Brinker, A.; Dixon, J.; Spitsin, S.; Flynn, J.; Matyszczuk, P.; Andryszak, K.; Laurelli, M.; et al. Tobacco as a production platform for biofuel: Overexpression ofArabidopsis DGATandLEC2genes increases accumulation and shifts the composition of lipids in green biomass. Plant Biotechnol. J. 2010, 8, 277-287. [CrossRef]

11. Leffingwell, J.C. Leaf Chemistry-Basic Chemical Constituents of Tobacco Leaf and Differences among Tobacco Types In Tobacco: Production, Chemistry, And Technology; Davis, D.L., Nielsen, M.T., Eds.; Blackwell Science: Hoboken, NJ, USA, 1999; pp. 265-284.

12. Tremblay, R.; Wang, D.; Jevnikar, A.M.; Ma, S. Tobacco, a highly efficient green bioreactor for production of therapeutic proteins. Biotechnol. Adv. 2010, 28, 214-221. [CrossRef]

13. Oeung, S.; Nov, V.; Ung, H.; Roum, K.; Yin, V.; Keo, S.; Chea, S. Phytochemical analysis of different extracts of leaves of Nicotiana tabacum L. of Cambodia. 2017. Asian J. Pharmacogn. 2017, 1, 18-26.

14. Banožić, M.; Babić, J.; Jokić, S. Recent advances in extraction of bioactive compounds from tobacco industrial waste-a review. Ind. Crop. Prod. 2020, 144, 112009. [CrossRef]

15. Charlton, A. Medicinal uses of tobacco in history. J. R. Soc. Med. 2004, 97, 292-296. [CrossRef] [PubMed]

16. Ujváry, I. Nicotine and Other Insecticidal Alkaloids. In Nicotinoid Insecticides and the Nicotinic Acetylcholine Receptor; Springer International Publishing: Berlin/Heidelberg, Germany, 1999; pp. $29-69$.

17. Fusetto, R.; O'Hair Richard, A.J. Nicotine as an Insecticide in Australia: A Short History. Available online: https:/ / search.informit. org/doi/epdf/10.3316/ielapa.531770497153501 (accessed on 8 January 2021).

18. López-Arrieta, J.; Sanz, F.J.F.J.S. Nicotine for Alzheimer's disease. Cochrane Database Syst. Rev. 2001, 2, CD001749. [CrossRef] [PubMed] 
19. Ebarreto, G.E.; Eiarkov, A.; Moran, V.E. Beneficial effects of nicotine, cotinine and its metabolites as potential agents for Parkinsonâ€ $€^{\mathrm{TM}_{\mathrm{S}}}$ disease. Front. Aging Neurosci. 2015, 6, 340. [CrossRef]

20. Akyazi, R.; Soysal, M.; Altunc, Y.E.; Lisle, A.; Hassan, E.; Akyol, D. Acaricidal and sublethal effects of tobacco leaf and garlic bulb extract and soft soap on Tetranychus urticae Koch. (Acari: Trombidiformes: Tetranychidae). Syst. Appl. Acarol. 2018, 23, 2054-2069. [CrossRef]

21. Raveen, R.; Kumar, L.; Sugirtha, A.; Karthikeyan, N.; Tennyson, S.; Arivoli, S.; Jayakumar, M. Efficacy of Tobacco Leaf Extracts on the Larva of the Dengue Vector Mosquito. J. Sci. Front. Res. 2019, 19, 7.

22. Choudhary, A.; Ashraf, S.; Musheer, N. Screening of phytoextracts to control of Fusarium oxysporum f.sp. vigni incitant of mungbean (Vigna radiata) wilt.2017. Int. J. Acad. Res. Dev. 2017, 2, 1181-1184.

23. Sharma, Y.; Dua, D.; Nagar, A.; Srivastava, N.S. Antibacterial activity, phytochemical screening and antioxidant activity of stem of Nicotiana tabacum. Int. J. Pharm. Sci. Res. 2016, 7, 1156-1167. [CrossRef]

24. Rymerson, R.T.; Menassa, R.; Brandle, J.E. Tobacco, a Platform for the Production of Recombinant Proteins. In Molecular Farming of Plants and Animals for Human and Veterinary Medicine; Erickson, L., Yu, W.-J., Brandle, J., Rymerson, R., Eds.; Kluwer Academic Publishers: Amsterdam, The Netherlands, 2002; pp. 1-31.

25. Beckman, C.H. Phenolic-storing cells: Keys to programmed cell death and periderm formation in wilt disease resistance and in general defence responses in plants? Physiol. Mol. Plant Pathol. 2000, 57, 101-110. [CrossRef]

26. Constabel, C.P.; Barbehenn, R. Defensive Roles of Polyphenol Oxidase in Plants. In Induced Plant Resistance to Herbivory; Schaller, A., Ed.; Springer: Dordrecht, The Netherlands, 2008; pp. 253-270.

27. Wang, H.; Zhao, M.; Yang, B.; Jiang, Y.; Rao, G. Identification of polyphenols in tobacco leaf and their antioxidant and antimicrobial activities. Food Chem. 2008, 107, 1399-1406. [CrossRef]

28. Hättenschwiler, S.; Vitousek, P.M. The role of polyphenols in terrestrial ecosystem nutrient cycling. Trends Ecol. Evol. 2000, 15, 238-243. [CrossRef]

29. Manach, C.; Scalbert, A.; Morand, C.; Rémésy, C.; Jiménez, L. Polyphenols: Food sources and bioavailability. Am. J. Clin. Nutr. 2004, 79, 727-747. [CrossRef]

30. Pandey, K.B.; Rizvi, S.I. Plant Polyphenols as Dietary Antioxidants in Human Health and Disease. Oxidative Med. Cell. Longev. 2009, 2, 270-278. [CrossRef] [PubMed]

31. Heimler, D.; Romani, A.; Ieri, F. Plant polyphenol content, soil fertilization and agricultural management: A review. Eur. Food Res. Technol. 2017, 243, 1107-1115. [CrossRef]

32. Rouphael, Y.; Colla, G.; Graziani, G.; Ritieni, A.; Cardarelli, M.; De Pascale, S. Phenolic composition, antioxidant activity and mineral profile in two seed-propagated artichoke cultivars as affected by microbial inoculants and planting time. Food Chem. 2017, 234, 10-19. [CrossRef]

33. Del Rio, D.; Rodriguez-Mateos, A.; Spencer, J.P.; Tognolini, M.; Borges, G.; Crozier, A. Dietary (Poly)phenolics in Human Health: Structures, Bioavailability, and Evidence of Protective Effects Against Chronic Diseases. Antiox. Redox Signal. 2013, 18, 1818-1892. [CrossRef]

34. Clifford, M.N.; Jaganath, I.B.; Ludwig, I.A.; Crozier, A. Chlorogenic acids and the acyl-quinic acids: Discovery, biosynthesis, bioavailability and bioactivity. Nat. Prod. Rep. 2017, 34, 1391-1421. [CrossRef]

35. Docheva, M.H.; Dagnon, S. Polyphenols in tobacco extracts obtained by macroporous resin. Compt. Rend. Acad. Bulg. Sci. 2015, 68, 183-190.

36. Docheva, M.H.; Staykova, M.B.; Stoilova, A.B.; Dimanov, D. Basic chemical components and radical scavenging activity of tobacco extracts obtained by macroporous resin. Bulg. Chem. Commun. 2017, 49, 212-216.

37. Dagnon, S.; Ivanov, I.; Bojilov, D.; Docheva, M.; Statkova, S. Evaluation of the Main Polyphenolic Compounds in Aromatic Plants of Asteraceae and Solanaceae Families of Bulgarian Origin. J. Pharmacogn. Phytochem. 2013, 1, 76-84.

38. Karabegović, I.T.; Veljković, V.B.; Lazić, M.L. Ultrasound-assisted Extraction of Total Phenols and Flavonoids from Dry Tobacco (Nicotiana tabacum) Leaves. Nat. Prod. Commun. 2011, 6, 1855-1856. [CrossRef] [PubMed]

39. Docheva, M.H.; Popova, V.T.; Ivanova, T.A.; Nikolova, V.V.; Hristeva, T.H.; Nikolov, N.N. Polyphenol content and anti-oxidant activity of aqueous/methanol extracts from different tobacco species (Nicotiana). Bulg. Chem. Commun. 2018, 50, 553-559.

40. Wang, X.; Liu, P.; Wang, F.; Fu, B.; He, F.; Zhao, M. Influence of altitudinal and latitudinal variation on the composition and antioxidant activity of polyphenols in Nicotiana tabacum L. leaf. Emir. J. Food Agric. 2017, 29, 359-366. [CrossRef]

41. Fu, B.; Ji, X.; Zhao, M.; He, F.; Wang, X.; Wang, Y.; Liu, P.; Niu, L. The influence of light quality on the accumulation of flavonoids in tobacco (Nicotiana tabacum L.) leaves. J. Photochem. Photobiol. B Biol. 2016, 162, 544-549. [CrossRef] [PubMed]

42. Re, G.A.; Piluzza, G.; Sanna, F.; Molinu, M.G.; Sulas, L. Polyphenolic composition and antioxidant capacity of legume-based swards are affected by light intensity in a Mediterranean agroforestry system. J. Sci. Food Agric. 2019, 99, 191-198. [CrossRef]

43. Nasr, S.B.; Aazza, S.; Mnif, W.; Miguel, M. Phenol content and antioxidant activity of different young and adult plant parts of tobacco from Tunisia, dried at 40 and $70{ }^{\circ} \mathrm{C}$. J. Appl. Pharm. Sci. 2014, 4, 023-031. [CrossRef]

44. Chen, Y.; Ren, K.; He, X.; Gong, J.; Hu, X.; Su, J.; Jin, Y.; Zhao, Z.; Zhu, Y.; Zou, C. Dynamic changes in physiological and biochemical properties of flue-cured tobacco of different leaf ages during flue-curing and their effects on yield and quality. BMC Plant Biol. 2019, 19, 1-21. [CrossRef] 
45. Torras-Claveria, L.; Jáuregui, O.; Codina, C.; Tiburcio, A.F.; Bastida, J.; Viladomat, F. Analysis of phenolic compounds by high-performance liquid chromatography coupled to electrospray ionization tandem mass spectrometry in senescent and water-stressed tobacco. Plant Sci. 2012, 182, 71-78. [CrossRef]

46. Sifola, M.I.; Postiglione, L. The effect of nitrogen fertilization and irrigation on dry matter partitioning, yield and quality of tobacco (Nicotiana tabacum L.) Burley type. Agric. Mediterr. 2002, 132, 33-43.

47. Sifola, M.I.; Carrino, L.; Cozzolino, E.; Ianuario, S.; Lucibelli, A.; Coppola, A. A Survey of Fertility Program Responses of Kentucky Dark Fire-Cured Tobacco (Nicotiana tabacum L.) Yield and Quality for Cigars Manufacture in the Benevento Province (Southern Italy). Beiträge Tab. Contrib. Tob. Res. 2018, 28, 14-29. [CrossRef]

48. Singleton, V.L.; Rossi, J.A. Colorimetry of total phenolics with phosphomolybdic-phosphotungstic acid reagents. Am. J. Enol. Vitic. 1965, 16, 144-158.

49. Brand-Williams, W.; Cuvelier, M.; Berset, C. Use of a free radical method to evaluate antioxidant activity. LWT 1995, 28, 25-30. [CrossRef]

50. Re, R.; Pellegrini, N.; Proteggente, A.; Pannala, A.; Yang, M.; Rice-Evans, C. Antioxidant activity applying an improved ABTS radical cation decolorization assay. Free Radic. Biol. Med. 1999, 26, 1231-1237. [CrossRef]

51. Graziani, G.; Ritieni, A.; Cirillo, A.; Cice, D.; Di Vaio, C. Effects of Biostimulants on Annurca Fruit Quality and Potential Nutraceutical Compounds at Harvest and during Storage. Plants 2020, 9, 775. [CrossRef]

52. MSTAC. A Microcomputer Program for Design Management and Analysis of Agronomic Research Experiments; Michigan State University: East Lansing, MI, USA, 1991.

53. Zhang, X.; Gao, H.; Zhang, L.; Liu, D.; Ye, X. Extraction of essential oil from discarded tobacco leaves by solvent extraction and steam distillation, and identification of its chemical composition. Ind. Crop. Prod. 2012, 39, 162-169. [CrossRef]

54. Selvamuthukumaran, M.; Shi, J. Recent advances in extraction of antioxidants from plant by-products processing industries. Food Qual. Saf. 2017, 1, 61-81. [CrossRef]

55. Galanakis, C.M. Handbook of Grape Processing By-Products: Sustainable Solutions; Academic Press: Cambridge, MA, USA, 2017; p. 293.

56. Van Zonneveld, M.; Ramirez, M.; Williams, D.E.; Petz, M.; Meckelmann, S.; Avila, T.; Bejarano, C.; Ríos, L.; Peña, K.; Jäger, M.; et al. Screening Genetic Resources of Capsicum Peppers in Their Primary Center of Diversity in Bolivia and Peru. PLoS ONE 2015, 10, e0134663. [CrossRef] [PubMed]

57. Barba, F.J.; Putnik, P.; Bursac Kovacevic, D. Agri-Food Industry Strategies for Healthy Diets and Sustainability: New Challenges in Nutrition and Public Health; Academic Press: Cambridge, MA, USA, 2020; p. 267.

58. Kerdraon, L.; Laval, V.; Suffert, F. Microbiomes and Pathogen Survival in Crop Residues, an Ecotone Between Plant and Soil. Phytobiomes J. 2019, 3, 246-255. [CrossRef]

59. Alibaba. Available online: https:/ /www.alibaba.com/premium/+extract_+polyphenol.html?src=sem_ggl\&cmpgn=10415283 818\&adgrp=106519962474\&fditm=\&tgt=kwd-914849910957\&locintrst=\&locphyscl=1008311\&mtchtyp=b\&ntwrk=g\&device= $c \& d v c m d l=\& c r e a t i v e=446020226116 \& p l c m n t=\&$ plcmntcat=\&p1=\&p2=\&aceid=\&position=\&gclid=EAIaIQobChMIgs3EuIiM7 gIVl7p3Ch2brQXdEAMYAyAAEgKK6_D_BwE (accessed on 8 January 2021).

60. Ru, Q.-M.; Wang, L.-J.; Li, W.-M.; Wang, J.-L.; Ding, Y.-T. In Vitro Antioxidant Properties of Flavonoids and Polysaccharides Extract from Tobacco (Nicotiana tabacum L.) Leaves. Molecules 2012, 17, 11281-11291. [CrossRef]

61. Sheen, S. The distribution of polyphenols, chlorogenic acid oxidase and peroxidase in different plant parts of tobacco, Nicotiana tabacum L. Phytochemistry 1969, 8, 1839-1847. [CrossRef]

62. Rodu, B.; Ou, B. The antioxidant properties of tobacco. Tob. Sci. 2000, 44, 71-73. [CrossRef]

63. Prior, R.L.; Cao, G. Antioxidant Phytochemicals in Fruits and Vegetables: Diet and Health Implications. HortScience 2000, 35, 588-592. [CrossRef]

64. Nickavar, B.; Esbati, N. Evaluation of the Antioxidant Capacity and Phenolic Content of Three Thymus Species. J. Acupunct. Meridian Stud. 2012, 5, 119-125. [CrossRef]

65. Ma, X.; Wu, H.; Liu, L.; Yao, Q.; Wang, S.; Zhan, R.; Xing, S.; Zhou, Y. Polyphenolic compounds and antioxidant properties in mango fruits. Sci. Hortic. 2011, 129, 102-107. [CrossRef]

66. Docheva, M.; Dagnon, S.; Statkova-Abeghe, S. Flavonoid content and radical scavenging potential of extracts prepared from tobacco cultivars and waste. Nat. Prod. Res. 2014, 28, 1328-1334. [CrossRef]

67. Shifflett, J.R.; Watson, L.; McNally, D.J.; Bezabeh, D.Z. Analysis of the Polyphenols of Tobacco Using Pressurized Liquid Extraction (PLE) and Ultra Performance Liquid Chromatography With Electrospray Ionization-Tandem Mass Spectometric Detection (UPLC-ESI-MS/MS). Beiträge Tab. Contrib. Tob. Res. 2017, 27, 195-207. [CrossRef]

68. Dagnon, S.; Edreva, A. Application of Pattern Recognition Method for Color Assessment of Oriental Tobacco based on HPLC of Polyphenols. Beiträge Tab. Contrib. Tob. Res. 2003, 20, 356-359. [CrossRef]

69. Sofic, E.; Copra-Janicijevic, A.; Salihovic, M.; Tahirovic, I.; Kroyer, G. Screening of medicinal plant extracts for querce-tin3rutinoside (rutin) in Bosnia and Herzegovina. Med. Plants Int. J. Phytomedicines Relat. Ind. 2010, 2, 97. [CrossRef]

70. Herrling, T.; Jung, K. The Radical Status Factor (RSF): A novel metric to characterize skin products. Int. J. Cosmet. Sci. 2012, 34, 285-290. [CrossRef]

71. Lorencini, M.; Brohem, C.A.; Dieamant, G.C.; Zanchin, N.I.; Maibach, H.I. Active ingredients against human epidermal aging. Ageing Res. Rev. 2014, 15, 100-115. [CrossRef] 
72. Jimenez-Lopez, C.; Fraga-Corral, M.; Carpena, M.; García-Oliveira, P.; Echave, J.; Pereira, A.G.; Lourenço-Lopes, C.; Prieto, M.A.; Simal-Gandara, J. Agriculture waste valorisation as a source of antioxidant phenolic compounds within a circular and sustainable bioeconomy. Food Funct. 2020, 11, 4853-4877. [CrossRef] [PubMed]

73. Tajik, N.; Tajik, M.; Mack, I.; Enck, P. The potential effects of chlorogenic acid, the main phenolic components in coffee, on health: A comprehensive review of the literature. Eur. J. Nutr. 2017, 56, 2215-2244. [CrossRef] [PubMed]

74. Santana-Gálvez, J.; Cisneros-Zevallos, L.; Jacobo-Velázquez, D.A. Chlorogenic Acid: Recent Advances on Its Dual Role as a Food Additive and a Nutraceutical against Metabolic Syndrome. Molecules 2017, 22, 358. [CrossRef] [PubMed] 